\title{
Analisis Wacana Kritis dan Studi Bahasa Kritis dalam Pengajaran BIPA
}

\author{
Ganjar Hwia \\ Tim BIPA Pusat Bahasa, Depdiknas
}

\begin{abstract}
Abstrak
Kerangka kerja analisis wacana kritis (AWK) relevan untuk pendekatan kritis terhadap studi bahasa-yang dikenal dengan studi bahasa kritis (SBK). SBK merupakan satu sumbangan penting dalam pendidikan dan pembelajaran bahasa yang mulai terkenal sekitar tiga dekade yang lalu. Relevansi AWK dengan SBK terletak pada orientasi atau pandangan terhadap bahasa dalam pendidikan dan pembelajaran bahasa (R. Fowler, et., 1979; M. Pecheux, 1982; J. Mey, 1985; N. Fairlough, 1989).

Dalam AWK, setiap wacana memiliki tiga dimensi: merupakan teks bahasa lisan maupun tertulis; suatu interaksi antar-orang-yang melibatkan proses produksi dan interpretasi teks (praktik kewacanaan); dan merupakan bagian dari suatu praktik atau tindak sosial. Implikasinya dalam SBK adalah bagaimana studi ini mengangkat kaidah bahasa dan praktik kebahasaan ditanamkan bersama dengan hubungan suatu praktik atau tindak sosial yang sering tidak disadari oleh kita selama ini. Studi ini pun mengkritik kecenderungan studi bahasa yang menggunakan kaidah dan praktik kebahasaan dengan begitu saja, sebagai objek yang dideskripsikan, dalam cara yang mengaburkan penanaman ideologi dan politik mereka.

Makalah ini akan membahas dalam tataran ide suatu pemikiran bidang AWK dalam hubungannya dengan SBK tentang pengajaran suatu bahasa sebagai bahasa asing (N. Fairlough, 1989; C. Wallace, 1992). Masalahnya difokuskan pada pengajaran membaca dengan latar belakang seringnya pelajar BIPA dianggap rendah sebagai pembaca sehingga ada yang hilang dalam pembelajarannya. Apa yang hilang itu adalah (1) usaha mendudukkan kegiatan membaca dan teks tulis dalam konteks sosial, (2) penggunaan teks yang provokatif, (3) cara penafsiran teks yang melibatkan asumsi-asumsi ideologis serta makna proposisional.
\end{abstract}




\section{Pendahuluan}

Makalah ini berangkat dari kerelevanan kerangka kerja analisis wacana kritis (AWK) dalam pendekatan kritis terhadap studi bahasayang dikenal dengan studi bahasa kritis (SBK). Kerelevanan ini didasarkan pada asumsi bahwa ilmu-ilmu sosial, termasuk linguistik, tidaklah netral. Ada banyak faktor yang memengaruhi perkembangannya, terutama faktor perubahan sosial kemasyarakatan. Ilmu-ilmu itu memiliki hubungan khusus dengan kelompok atau kekuatan yang dominan atau yang didominasi dan memberikan sumbangan yang terkait dengan perjuangan sosial tertentu.

Dalam hal ini, SBK melihat dirinya sebagi sumber untuk mengembangkan kesadaran, khususnya mereka yang didominasi caracara linguistik. Tentu saja dominasi linguistik cenderung terjadi bersamasama dengan bentuk dominasi lain. Kesadaran dalam konteks ini dipandang sebagai prasyarat awal yang diperlukan untuk pengembangan praktik-praktik dan kaidah baru yang dapat memberi sumbangan terhadap emansipasi sosial terhadap apa yang barangkali dinamakan praktik wacana. Sedangkan dalam pandangan AWK, pembentukan wacana itu oleh masyarakat dan masyarakat oleh wacana merupakan salah satu sisi dari praktik jangka panjang yang mengatur kembali struktur sosiolinguistik. Di sisi lain pembentukan itu merupakan proses yang memengaruhi setiap hal yang berkaitan dengan wacana.

Makalah ini akan mendeskripsikan secara garis besar kerangka kerja AWK dalam SBK yang berhubungan dengan cara menganalisis halhal tertentu dari wacana dengan mengangkat pentingnya proses ini untuk melakukan analisis wacana untuk pemahaman bacaan. Makalah ini hanya sebatas menjawab pertanyaan korelasional seperti "bagaimanakah peran 
SBK dan AWK dalam pemahaman bacaan (reading comprehension) dalam bahasa kedua?” dan bukan untuk menjawab bentuk pertanyaan eksperimental seperti "Apakah pendekatan SBK dan AWK menyebabkan pemahaman bacaan (maha)siswa menjadi lebih baik?" Makalah ini pun hendak meninjau secara umum keterhubungan yang diperkirakan terjadi antara AWK dan SBK dalam pengajaran bahasa, khususnya pengajaran bahasa Indonesia untuk penutur asing (BIPA).

\section{Studi Bahasa Kritis}

SBK memandang bahwa perkembangan mencapai kesadaran kritis terhadap dunia (dan segala kemungkinan yang bisa mengubahnya) seyogianya menjadi tujuan utama dari semua pendidikan, termasuk pendidikan (dan pembelajaran) bahasa. Perspektif tentang kesadaran kritis ini secara mengesankan digambarkan oleh Paulo Freire sebagai berikut.

Apakah itu rintik hujan yang akan turun (tetapi beku) yang menjadi hujan butiran-butitan es kecil yang indah; seekor burung yang bernyanyi; sebuah bus yang melaju; preman di jalanan; headline di surat kabar; pidato politik; sebuah penolakan cinta; atau apa saja ... kita harus menggunakan pandangan kritis, seperti orang yang bertanya, yang ragu, yang menyelidiki, dan seperti siapa saja yang ingin membuat terang kehidupan yang kita jalani ....

Freire sebagai penggagas gerakan "penyadaran" mengatakan bahwa agar manusia bisa mengenal realitas diri sendiri dan lingkungannya sekaligus jika ia memunyai kesadaran kritis. Minimal dengan bekal kesadaran itu, manusia bisa memahami kondisi dirinya sendiri serta mampu menganalisis persoalan-persoalan yang menyebabkan timbulnya masalah. 
Freire mendeskripsikan kesadaran kritis sebagai sebuah proses untuk menjadi manusia yang utuh. Gagasan ini digunakan untuk meneropong pola sikap manusia tertindas, serta bagaimana pola sikap selanjutnya agar terbebas dari penindasan. Dalam hal ini Freire memetakan tipologi kesadaran manusia dalam empat kategori, yaitu kesadaran magis (magic conscousness), kesadaran naif (naival consciousness), kesadaran kritis (critical consciousness) dan yang paling puncak adalah kesadaran transformasi (transformation consciousness).

Pertama, kesadaran magis merupakan jenis kesadaran paling determinis. Kesadaran ini melihat faktor di luar manusia (natural maupun supranatural) sebagai penyebab ketertindasan dan ketakberdayaan. Kesadaran ini sepadan dengan paradigma cara berpikir bahwa segala penyebab dari ragam masalah adalah takdir. Bahkan dalam menghadapi kehidupan sehari-hari, ia lebih percaya pada kekuatan takdir yang telah ditentukan. Bahwa ia hidup miskin, bodoh, terbelakang, dan sebagainya adalah suatu "suratan takdir" yang tidak bisa diganggu gugat. Cara berpikir magis ini dalam perkembangannya kemudian berubah menjadi watak manusia yang status quo: fatalis, fasis, superior, mandeg, dan segala sesuatunya netral — tidak ada kepentingan dalam setiap realitas.

Kedua, kesadaran naif. Kesadaran ini ada dalam diri manusia sebatas baru mengerti, tetapi kurang bisa menganalisis persoalanpersoalan sosial yang berkaitan dengan unsur-unsur yang menyebabkan masalah itu. Manusia dalam kesadaran ini baru sekadar mengerti bahwa dirinya itu tertindas dan terbelakang. Ia kurang mampu untuk memetakan secara sistematis persoalan-persoalan yang mendukung suatu problem sosial itu. Apalagi untuk mengajukan suatu tawaran solusi dari problem sosial. 
Kesadaran naif ini sejalan dengan paradigma liberal yang memandang bahwa manusialah sumber dari berbagai persoalan sosial. Cara berpikir ini tampak jelas pada manusia-manusia yang menganggap bahwa akar masalah terletak pada masalah motivasi (need for achievement), "etika", kreatifitas, sumber daya manusia, kompetisi, dan transparansi. Ia tidak menyadari adanya faktor kekuasaan struktural, seperti negara dan pemilik modal. Oleh karena itu, pemikiran yang dihasilkan adalah pemikiran yang berorientasi pada pasar dan bukan pada bagaimana memandang "kemanusiaan" manusia.

Mengapa hal itu terjadi? Ketika manusia berkejar-kejaran untuk meraih prestasi melalui kompetisi, kehidupannya akan dipenuhi dengan "bagaimana menjadi yang terbaik" tanpa berpikir bahwa hasil terbaik yang diperolehnya berasal dari derita manusia lainnya. Contoh jejaknya bisa kita lihat dari produk film-film Holywood dan Bolywood yang bermodal besar dan sekedar mengeruk keuntungan dari pasar. Produk film mereka yang sekarang banyak beredar pada umumnya menganut cara berpikir demikian. Mereka tidak berpikir bahwa film-film yang dibuat ikut mengukuhkan kesadaran naif manusia. Yaitu, cara untuk menjadi seorang kompetitor tercanggih, terbaik, dan yang paling berkuasa adalah dengan cara menguasai dan memunyai kemampuan individu dalam membangun korporasi dan memainkan kebijakan negara.

Ketiga, kesadaran kritis adalah sebuah kesadaran yang melihat adanya keterkaitan antara ideologi dan struktur sosial sebagai akar masalah. Kesadaran ini jenis dianggap paling ideal di antara jenis kesadaran sebelumnya karena bersifat analitis sekaligus praksis. Kesadaran ini mendorong seseorang mampu memahami persoalan sosial mulai dari pemetaan masalah, identifikasi, serta mampu menentukan 
unsur-unsur yang mempengaruhinya dan menawarkan solusi-solusi alternatif.

Kesadaran kritis mengarahkan analis pada struktur dan sistem sosial, politik, ekonomi, gender, budaya, serta akibatnya pada masyarakat. Implikasi dari kesadaran kritis adalah adanya upaya "belajar bersama" untuk membangun dialog demi perubahan yang lebih baik dan bermakna. Konsekuensi yang diharapkan adalah pelaku atau organisasi yang menggunakan pendekatan demikian memandang bahwa manusiadirinya dan manusia lain_-adalah subyek dari perubahan. Ia berpihak pada pembelaan terhadap ketertindasan rakyat, baik secara sektoral, kelas, bahasa, gender, ilmu pengetahuan, dan aktivitas sosial. Metode yang digunakan berupa riset aksi-partisipatoris, rakyat tertindaslah yang berbicara dan sang kreator sekedar memfasilitasi dan "belajar bersama" untuk bersama-sama menyelesaikan masalah dengan melakukan praksis gerakan.

Keempat, kesadaran transformatif, yaitu puncak dari kesadaran kritis. Dalam istilah lain kesadaran ini adalah "kesadarannya kesadaran" (the conscie of the consciousness). Orang makin praksis dalam merumuskan suatu persoalan. Antara ide, perkataan dan tindakan serta progresifitas dalam posisi seimbang. Kesadaran transformatif akan menjadikan manusia itu betul-betul dalam derajat sebagai manusia yang sempurna.

Setakat ini, maksud dari pendekatan kesadaran kritis terhadap studi bahasa memerlukan penjelasan yang lebih banyak. Oleh karena itu, SBK didudukkan bukan sebagai cabang dari studi bahasa, melainkan suatu orientasi atau pandangan terhadap bahasa. Norman Fairclough (1992) mengatakan bahwa SBK ini baru dalam tahap embrio suatu teori bahasa dengan implikasi bagi berbagai cabangnya. 
SBK semakin menarik dicermati karena studi ini mencoba mengangkat bagaimana kaidah bahasa dan praktik bahasa ditanamkan secara bersamaan dengan hubungan kekuasaan dan proses ideologi yang sering tidak disadari oleh manusia. SBK pun mengkritik kecenderungan studi bahasa yang menggunakan kaidah dan praktik kebahasaan dengan begitu saja—sebagai objek yang dideskripsikan—dalam cara yang mengaburkan penanaman ideologi dan politik mereka.

Namun, sebenarnya SBK ini juga bukan hal baru. Studi ini merupakan satu sumbangan penting dalam pendidikan dan pembelajaran bahasa yang mulai terkenal sekitar tiga dekade yang lalu, seperti dalam buku Language and Control (1979) karya R. Fowler, R. Hodge dan G. Kress dan T. Trew, buku Language, Semantics and Ideology: Stating the Obvious (1982) karya M. Pecheux, buku Whose Language? A Study of Linguistics Pragmatics (1985) karya J. Mey, dan buku Language and Power (1989) karya N.Fairlough. Pengaruh-pengaruh penting terhadap SBK ini juga dapat ditelusuri dalam teori sosial Pierrer Bourdieu, Michael Foulcault, dan Jurgen Habermas yang memokuskan pada bahasa dan teori-teori wacana-yang berkaitan lebih erat dengan perkembangan berpikir tentang ideologi dan masalah-masalah sosial.

\section{Analisis Wacana Kritis}

Analisis wacana kritis (AWK) merupakan salah satu bagian dari analisis wacana. Dalam AWK, wacana tidak dipahami semata sebagai studi bahasa. Menurut Fairclough dan Wodak (1997), AWK melihat wacana sebagai bentuk dari praktik sosial sehingga perlu diperhatikan kriteria yang holistik dan kontekstual.

Kualitas suatu wacana kritis akan selalu dinilai dari segi kemampuan menempatkan teks pada konteks yang utuh. Wacana tidak 
lagi dipahami sekadar serangkaian kata atau proposisi dalam teks, tetapi sebagai sebuah gagasan, konsep atau efek yang dibentuk dalam suatu konteks tertentu sehingga memengaruhi cara berpikir dan bertindak. Untuk mengenali suatu analisis wacana kritis perlu diketahui lima ciri umum sebagai berikut.

a) Sifat struktur dan proses kultural dan sosial yang memandang teks sebagai bentuk praktik sosial dan teks sebagai sebagian fenomena kemasyarakatan yang tidak selamanya bersifat linguistik-kewacanaan.

b) Wacana tersusun dan bersifat konstitutif, artinya wacana merupakan bentuk praktik sosial, dan memiliki hubungan dialektik dengan dimensi-dimensi sosial yang lain.

c) Penggunaan bahasa hendaknya dianalisis secara empiris dalam konteks interaksi sosial.

d) Fungsi Wacana secara ideologis. Dalam analisis ini praktik kewacanaan memberikan kontribusi kepada penciptaan dan pereproduksian hubungan kekuasaan yang tidak setara antarkelompok-kelompok sosial seperti kelas-kelas sosial, perempuan dan laki-laki, kelompok minoritas dan mayoritas,dan lainnya.

e) Penelitian dilakukan dengan tujuan menguak peran praktik kewacanaan dalam melestarikan hubungan kekuasaan yang tidak setara.

Pendekatan Fairclough (1995) secara lebih khusus merupakan pendekatan bentuk wacana analisis yang berorientasi pada teks dan yang berusaha menyatukan tiga tradisi, yaitu analisis tekstual yang terinci di bidang linguistik, analisis makro-sosiologis/praktik sosial, dan tradisi interpretatif dan mikro-sosiologis (termasuk etnometodologi dan analisis percakapan). Dalam wacana seperti ini kehidupan sehari-hari diperlakukan sebagai produk tindakan orang-orang 
Selain itu wacana juga diterapkan oleh Fairclough dalam tiga konsep yang berbeda. Pertama, wacana dipahami sebagai jenis bahasa yang dipergunakan dalam suatu bidang tertentu, seperti politik atau ilmiah. Kedua, penggunaan wacana sebagai praktik sosial, artinya analisis wacana bertujuan untuk mengungkap peran praktik kewacanaan dalam upaya melestarikan dunia sosial, termasuk hubungan-hubungan sosial yang melibatkan kekuasaan yang tak sepadan. Kekuasaan menurut Fairclough tidak datang dari luar tetapi menentukan susunan, aturan, dan hubungannya dengan faktor lain seperti sosial ekonomi, keluarga, media komunikasi, pendidikan dan ilmu pengetahuan.

Ketiga dalam penggunaan yang paling kongkret, wacana digunakan sebagai suatu cara bertutur yang memberikan makna yang berasal dari pengalaman yang dipetik dari perspektif tertentu. Oleh karena itu dalam tatanan wacana terdapat praktik-praktik kewacanaan tempat dihasilkan dan dikonsumsi atau diinterpretasikan teks dan pembicaraan.

Tiga konsep Fairclough yang telah diungkapkan di atas dirumuskan menjadi suatu kerangka analisis wacana Fairclough dengan pemahaman bahwa setiap peristiwa penggunaan bahasa merupakan peristiwa komunikatif yang terdiri atas tiga dimensi berikut ini.

(1) Teks (tuturan), pada tataran ini analisis dipusatkan pada ciri-ciri formal seperti kosakata, tata bahasa, sintaksis dan koherensi kalimat. Piranti yang diusulkan oleh Fairclough untuk menganalisis teks tersebut adalah sebagai berikut.

a) kendali intertekstual (hubungan antara penutur dengan penutur lainnya, termasuk siapa yang menentukan agenda percakapan),

b) etos yaitu bagaimana identitas dikonstruk melalui bahasa dan aspek-aspek tubuh 
c) metafora

d) kata dan tatabahasa

Dari analisis inilah diwujudkan wacana secara linguistis. Dalam analisis ini tidak dapat dihindarkan keterlibatan analisis praktik wacana.

(2) Praktik kewacanaan, tataran ini merupakan tempat di mana pengarang bergantung pada wacana dan aliran yang ada untuk menciptakan suatu teks dan bagaimana penerima teks menerapkan aliran dan wacana yang ada dalam mengkonsumsi dan menginterpretasikan teks.

(3) Praktik sosial, analisis wacana tidak cukup memadai untuk menganalisis praktik sosial, karena analisis wacana hanya memberi tuntunan bagi unsur kewacanaan dan non-kewacanaan. Untuk itu diperlukan teori sosial dan kultural. Dengan demikian terlihat bahwa peristiwa komunikatif membentuk dan dibentuk oleh praktik sosial yang lebih luas melalui hubungannya dengan tatanan wacana. Oleh karena setiap peristiwa komunikatif berfungsi sebagai bentuk praktik sosial dalam memreproduksi tatanan wacana, analisis wacana kritis ini menekankan pada multilevel analisis, yaitu mempertautkan analisis pada jenjang mikro (teks) dengan analisis pada jenjang meso ataupun makro dengan cara memaknai temuan dalam konteks serta situasi tertentu (praktik sosial). Prinsip yang mendasari kerangka tiga dimensi Fairclough ini adalah bahwa teks tidak pernah bisa dipahami atau dianalisis secara terpisah, namun harus dipahami dalam kaitannya dengan konteks sosial dan jaring teks lain.

Tiga dimensi tersebut, yaitu teks, praktik kewacanaan, dan praktik sosial, dapat digambarkan pada Gambar 1 berikut. 


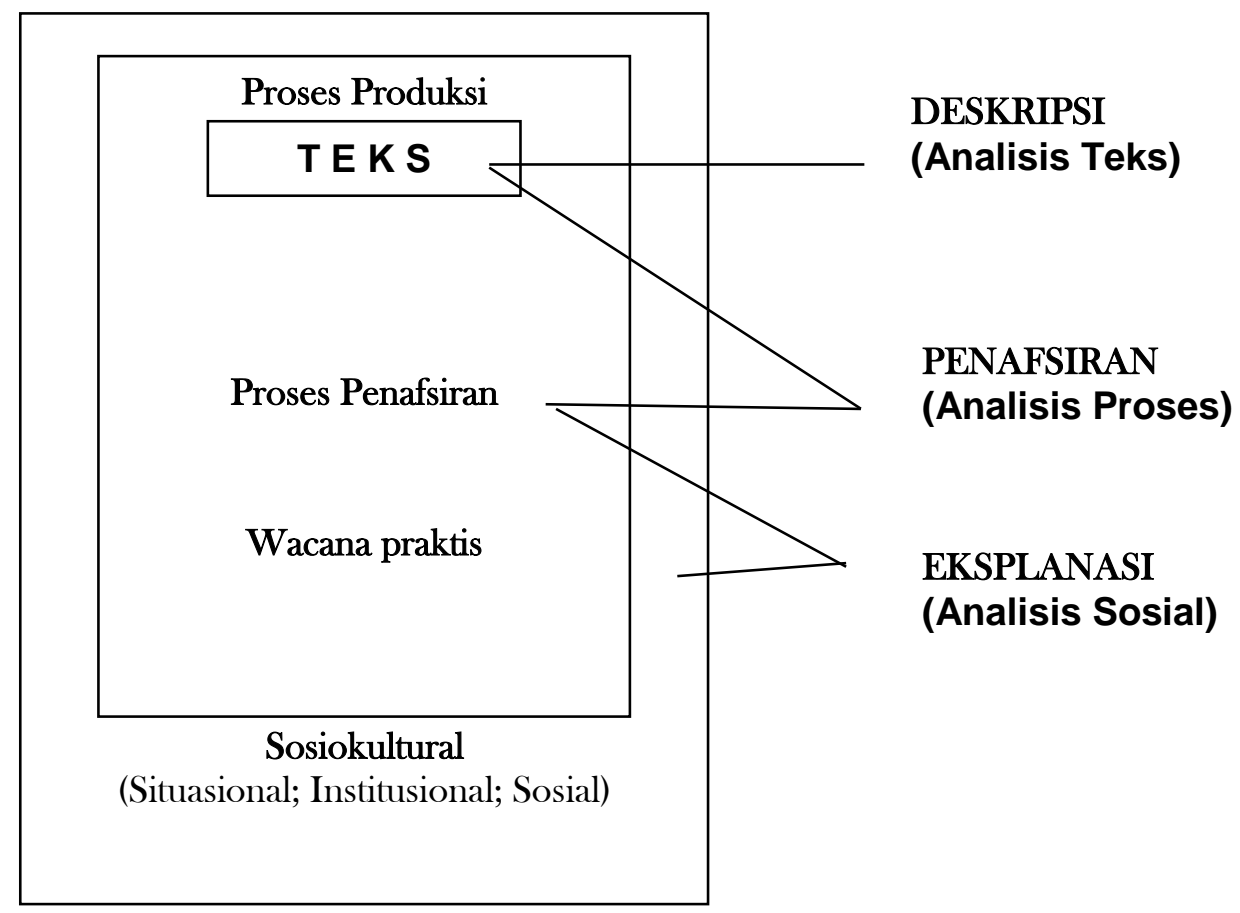

Gambar 1. AWK Norman Fairclough

Fairclough menganggap bahwa untuk memperoleh pemahaman teks secara utuh, analisis itu harus diletakkan dalam sebuah konteks sosiokultural dan latar belakang aktor pembuat teks itu.

AWK dari Ruth Wodak menyajikan model seperti tampak dalam Gambar 2. Model ini melihat naskah memiliki sejarah perjalanannya, sehingga ia dikenal dengan Discourse-Historical Method. Perjalanan tersebut bukan saja terjadi pada dimensi bahasa melainkan juga pada dimensi pemikiran si pembuat naskah. Keduanya dipengaruhi oleh dimensi psikologis si pembuat naskah yang berinteraksi dengan situasi dan kondisi komunikasi. 
SKEMA

DIMENSI

KOGNITIF
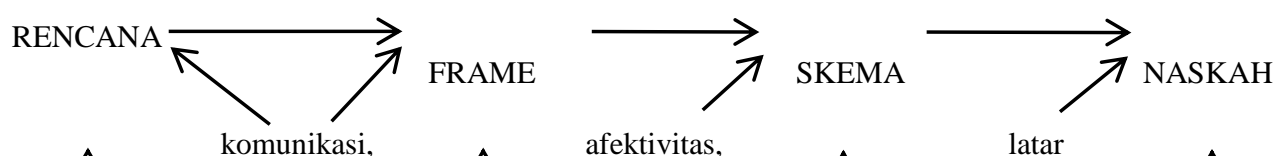

DIMENSI

SOSIAL-

PSIKOLOGIS

DIMENSI

LINGUISTIK
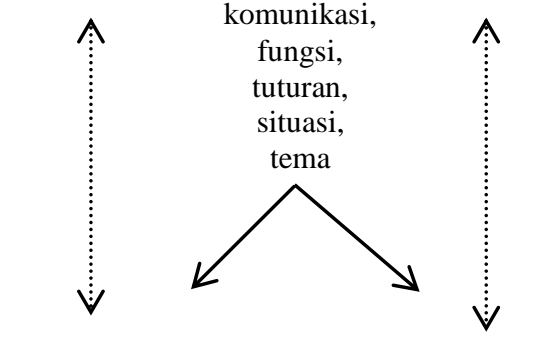

afektivitas,

gender,

tingkat

penutur, tipe

konflik
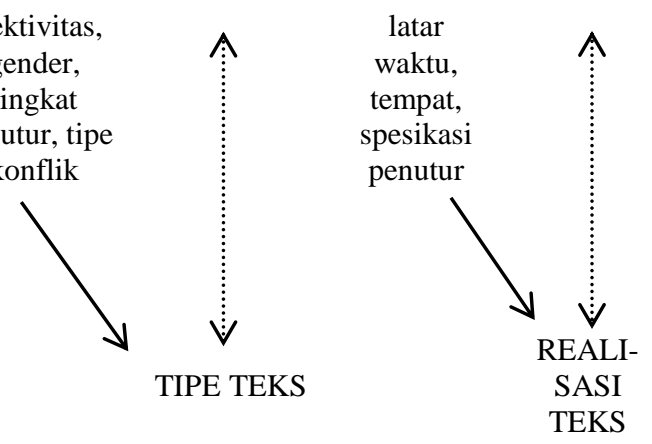

TEMATIK

JENIS

STRUKTU

TEKS

TEKS

Gambar 2. Model AWK Ruth Wodak

\section{Hubungan Studi Bahasa Kritis, Analisis Wacana Kritis, dan Pengajaran (Membaca dalam) BIPA}

Di kelas, setelah membaca suatu wacana tulis kita mungkin pernah berusaha mengajak (maha)siswa kita untuk merekontruksi tulisan yang memunyai tujuan dan tema khusus. Biasanya kita menggunakan suatu rancangan yang lengkap dan rinci mengenai aspek-aspek pokok masalahnya. Rancangan ini diharapkan menjadi suatu panduan agar jalan pikiran dan pembahasan masalahnya tidak menyimpang. Atau dengan kata lain, pemahaman suatu wacana tulis dengan tujuan khusus harus berangkat dari rincian ide/gagasan dan dikembangkan menurut rincian perencanaan ruang lingkup masalahnya.

Secara teknis, rancangan itu bisa dibuat dengan cara membagi halaman kertas kosong dengan dua kolom (kolom kanan lebih besar dari kolom kiri). Pada kolom kiri kita tuliskan rincian ide dari pokok masalahnya dan kolom kanan berisi materi kasar berupa paragraf rancangan pendek (paragraf-outline) yang kita atau (maha)siswa kutip 
berdasarkan ingatan terhadap isi wacana. Tiap paragraf rancangan pendek itu hendaknya terdiri dari pikiran utama dan beberapa subgagasan yang berhubungan secara langsung dan relevan dengan pikiran utama wacana tersebut.

Biasanya, rancangan yang dibuat didahului oleh judul atau topik, tipe wacana yang kita inginkan, dan penafsiran terhadap judul/topik atau ruang lingkup pokok masalahnya. Penafsiran ini merupakan satu rumusan gagasan atau ide dasar yang ditulis dalam sebuah kalimat rumusan yang biasa kita sebut kalimat tesis.

Atau, kita di kelas sering memulai pengajaran membaca yang sudah sangat biasa, bahkan usang, yakni membaca yang tersirat (reading between the lines). Jika kita sepakat bahwa ini termasuk pengajaran membaca yang efektif dan jika benar banyak orang membaca tidak dengan cara ini, mungkinkah dan tepatkan kita sebagai guru mencoba mengembangkan keterampilan ini? Istilah itu biasanya diartikan sebagai "menarik kesimpulan", tetapi hakekat simpulan ini tidak selalu dituntaskan. Misalnya, apakah simpulan itu merupakan yang diinginkan penulis atau bukan; apakah kita pembaca bebas dalam menyimpulkan, sesuatu yang hampir selalu bukan yang dimaui penulis.

Yang menjadi pertanyaannya sekarang, apakah model pembelajaran membaca semacam itu, atau model lain yang hanya mengajukan pertanyaan standar seperti who, when, why, where, which, dan how tentang ingatan isi wacana, dapat menumbuhkan kesadaran bahasa kritis? Untuk pemelajar BIPA di tingkat pemula, pertanyaan standar itu mungkin bisa membantu memahami isi bacaan. Lalu, bagaimana jika pembelajaran membaca semacam itu diterapkan pada pemelajar bahasa Indonesia untuk penutur asing (BIPA) di tingkat mahir? 
Padahal, dalam hubungannya dengan retensi atau kemampuan mengingat kembali unsur-unsur bahasa yang sudah dipelajari, kemahiran membaca mempunyai derajat yang paling rendah. Seperti dilaporkan oleh Cone Dale (1969), dalam bukunya Education Media, pada umumnya pemelajar hanya $10 \%$ mengingat dari apa yang mereka baca, $20 \%$ dari apa yang mereka dengar, 30\% dari apa yang mereka lihat, 50\% dari apa yang mereka dengar dan lihat, 70\% dari apa yang mereka katakan dan tulis, dan 90\% dari apa yang mereka katakan seperti yang mereka lakukan. Mengingat rendahnya kemampuan mengingat dari apa yang mereka baca dan dengar dalam proses belajar bahasa asing, maka pelajaran membaca, mendengar, dan berbicara harus mendapat perhatian yang seksama.

Masalah tersebut menjadi menarik ketika difokuskan pada pengajaran membaca dengan latar belakang seringnya pemelajar BIPA dianggap rendah sebagai pembaca sehingga ada yang hilang dalam pembelajarannya. Apa yang hilang itu adalah (1) usaha mendudukkan kegiatan membaca dan teks tulis dalam konteks sosial, (2) penggunaan teks yang provokatif, (3) cara penafsiran teks yang melibatkan asumsiasumsi ideologis serta makna proposisional.

SBK dan AWK sebenarnya terkait dengan pandangan bahwa kesadaran memengaruhi 'kompetensi' atau kesadaran memengaruhi kemampuan berbahasa. Dalam hal ini, tema utama dalam SBK dan AWK adalah kesadaran kritis terhadap bahasa harus sepenuhnya dipadukan dengan perkembangan praktik dan kemampuan menganalis bahasa. 
Gambar berikut memberikan satu contoh integrasi atau hubungan ini.

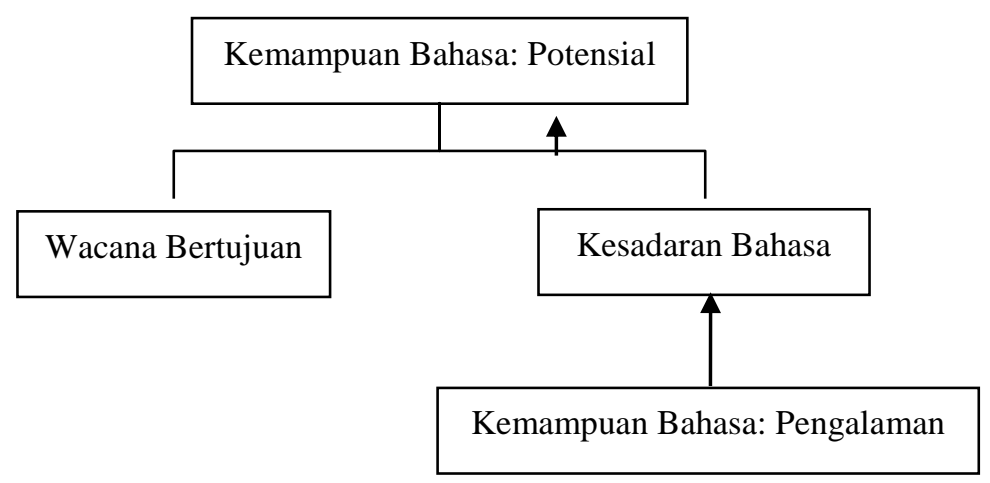

Model ini memasukkan prinsip penting bahwa kesadaran bahasa kritis (critical language awareness, CLA) harus dibentuk dari kemampuan dan pengalaman bahasa (maha)siswa yang sudah ada. Pengalaman yang telah dimiliki oleh (maha)siswa-dengan bantuan guru-dapat dibuat secara eksplisit dan sistematik sebagai pokok pengetahuan yang dapat digunakan untuk diskusi dan refleksi sehingga pengalaman yang ditimbulkan oleh keadaan sosial (misalnya, hal yang bersifat mendesak atau terpaksa) dapat digali. Sehubungan dengan itu, kesadaran bahasa kritis perlu dibedakan dengan sekadar "kesadaran bahasa" (language awareness, LA). Kesadaran bahasa kritis lebih dari sekadar "kesadaran bahasa". Kesadaran bahasa hanya knowledge about language, sedangkan kesadaran bahasa kritis adalah awareness of nontransparent aspects of the social functioning of language.

Kesadaran bahasa kritis dengan SBK pada akhirnya bertujuan untuk menuntun pembaca dalam memahami-menurut Julia Kristeva (1980) — intertekstualitas. Misalnya, ketika (maha)siswa diajak membaca artikel-artikel atau berita-berita tentang polemik pembubaran Ahmadiyah. Artikel atau berita tentang Ahmadiyah di sini bukan teks 
yang berdiri sendiri, melainkan saling terkait dengan "teks-teks" lain yang "ditulis" para pelakunya lewat perbuatan apa pun sebelum dan setelah kejadian di Monas Jakarta tanggal 1 Juni 2008.

Dalam kacamata AWK, tragedi di Monas itu, isu pembubaran Ahmadiyah, pembubaran Front Pembela Islam (FPI), keputusan politik Surat Keputusan Bersama (SKB) tentang Ahmadiyah, penyerahan diri Munarman sebagai Panglima Komando Laskar Islam (KLI), debat-debat publik, kelegalitasan Undang-Undang Nomor 1 Tahun 1965 (1/PNPS/1965) tentang Pencegahan Penyalahgunaan dan/atau Penodaan Agama, serta reaksi sejumlah ulama dan pejabat semua itu adalah teks. Jika demikian, isu-isu tentang Ahmadiyah itu justru dilakukan oleh para pemerannya sendiri. Oleh mereka yang berkepentingan, dan kepentingan itu secara jujur-meski samar-samar-mewujud sebagai "teks". Bagaimana nasib Ahmadiyah beserta berbagai kepentingan di balik tidak tegasnya SKB? Kita dapat mendiskusikannya dengan (maha)siswa, dan tentunya dengan prasangka kritis.

Dalam konteks pengajaran BIPA, pemahaman bacaan tentang isuisu kontroversial itu, dalam waktu yang bersamaan harus juga dijalin hubungan yang konstan antara pengembangan kesadaran bahasa dan praktik bahasa yang dilakukan oleh (maha)siswa. Praktik itu harus memiliki 'tujuan'. Yaitu, harus dikaitkan dengan orang tertentu atau latar belakang ideologi bangsanya karena ini merupakan salah satu cara bagi (maha)siswa untuk memperoleh pengalaman dan keuntungan dari keputusan tertentu. Kesadaran kritis yang dihubungkan dengan keputusan demikian ini akan memperluas ruang lingkup untuk menyertakan keputusan mengenai apakah mencemooh konvensi teks, mengkritik, menyetujui, ataukah mengikutinya, apakah menyesuaikan ataukah tidak. Hal ini juga memungkinkan adanya keputusan yang sedemikian rupa 
untuk dilihat sebagai "yang ada" dalam lingkungan tertentu, kumpulan, dan bukannya perorangan, menyatu dengan strategi politik kelompok.

Secara ringkas, makalah ini ingin mengatakan bahwa membaca efektif melibatkan tantangan terhadap asumsi-asumsi ideologis serta pengetahuan proposional teks tertulis dan bahwa kita sebagai guru perlu membimbing (maha)siswa ke kesadaran isi ideologis karena begitu seringnya dinyatakan 'jelas'. Kita patut mengingat pendapat Robert Scholes yang mengatakan bahwa pada zaman manipulasi ketika (maha)siswa sangat memerlukan kekuatan kritis untuk bertahan terhadap pembantaian media yang terus-menerus, hal paling jelek yang bisa kita lakukan adalah mendorong mereka bersikap hormat terhadap teks. Tentu saja ada resiko dalam membaca dengan sikap terlalu menentang, dan Scholes sudah mengingatkannya.

Namun, kecenderungan umum 'khususnya bagi pembaca bahasa kedua' pendirian terlalu hormat terhadap teks adalah lazim. Dalam hal ini SBK dengan cara kerja AWK menyarankan beberapa pendekatan pedagogis yang bisa membantu pembaca bertahan terhadap jenis pembantaian tertentu oleh teks tertulis dan membangun kesadaran kritisnya, yakni cara untuk berbicara tentang orang, tempat, kejadian/fenomena dan cara berbicara kepada pembaca dengan menempatkan mereka pada posisi tertentu. Lagi pula, membaca kritis melibatkan lebih dari tanggapan kritis terhadap teks itu sendiri. Membaca kritis melibatkan kesadaran kritis dalam arti yang lebih luas terhadap apa membaca itu sebenarnya, yang seterusnya melibatkan pertimbangan aspek-aspek lintas budaya dengan melihat siapa yang membaca, apa, mengapa, dan bagaimana situasinya. 


\section{Penutup}

Membaca kritis pada umumnya belum digalakkan dalam pengajaran BIPA khususnya pengajaran bahasa Indonesia di perguruan tinggi, baik pada tingkat pemula maupun pada tingkat lanjut. (Maha)Siswa cenderung tidak dihadapkan pada usaha mengungkap pemahaman wacana sebagai fenomena sosial. Membaca dipandang sebagai kegiatan yang tidak bermasalah. Teks umumnya tidak dipilih atas dasar kekuatan menantangnya. Wacana lebih dilihat sebagai wahana struktur linguistik - sebagai materi ringan yang banyak disenangi orang atau sebagai materi "tujuan khusus" bagi kelompok pemelajar BIPA yang berupa, misalnya, teks yang bersedia menampung informasi dan berkaitan dengan pekerjaan dari pemelajar BIPA.

Alasan yang sering diajukan untuk menghindari pemakaian materi yang mengandung perdebatan atau kontroversial adalah bahwa (maha)siswa yang berlatar budaya berbeda dengan Indonesia akan menganggap materi yang bersangkutan tak sesuai dan akan menyinggung perasaannya. Tetapi, alasan resiko semacam itu terlalu dilebihkan. Setidaknya pemelajar BIPA dewasa cenderung lebih terhina oleh dipilihnya teks secara kaku dan dipilihnya teks-teks untuk menutupi fakta keadaan sosial keindonesiaan.

Saya yakin pemelajar dewasa tidak ingin diperlakukan berbeda dari masyarakat pembaca lainnya hanya karena mereka orang asing dan berada di kelas sebagai yang diajar. Mereka ingin menjadi seperti katakata Frank Smith (1983) dalam makalahnya yan disajikan di The

Seventeenth Annual Convention of Teacher of English to Speakers of Other Language, yang kini terkenal sebagai "anggota keluarga" (one of the $(l u b)$. Singkat kata, seperti di katakan di atas, pemelajar BIPA sering dianggap rendah sebagai pembaca sehingga ada yang hilang dalam 
Analisis Wacana Kritis dan ...

pembelajarannya. Tujuan pembelajarannya mereka berinteraksi dengan teks tulisnyalah yang selalu diutamakan. 


\section{Daftar Pustaka}

Fairclough, Nourman. 1989. Language and Power. Harlow: Longman.

Fairclough, Nourman. 1992. Discourse and Social Change. Cambridge: Polity Press.

Fairclough, Nourman. 1995a. Critical Discourse Analysis: The Critical Study of Language London: Longman.

Fairclough, Nourman. 1995b. Media Discourse. London: Edward Arnold.

Fairclough, Nourman. 1995. Kesadaran Bahasa Kritis (terjemahan). Semarang: IKIP Semarang Press.

Freire, Paulo. 1985 The Politics of Education: Culture, Power, and Liberation. London: MacMillans Publishers Ltd.

Philips, Louise J dan Marianne W. Jorgensen. 2002. Discourse Analysis as Theory and Method. London: SAGE Publications.

Scholes, Robert. 1985. Textual Power: Literary Theory and the Teaching of English. New Haven: Yale University Press.

Sudaryono. 2001. "Pemakaian 'Authentic Materials' dalam Pengajaran Bahasa Indonesia bagi Penutur Asing", makalah Konferensi Internasional Pengajaran Bahasa Indonesia bagi Penutur Asing IV, tanggal 1 - 3 Oktober 2001, Sanur-Bali.

Titscher, Stefan, M. Meyer, R. Wodak, dan E. Vetter. 2000. Methods of Text and Discourse Analysis. London: Sage Publication. 